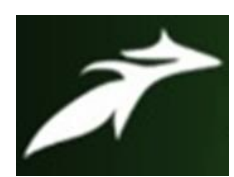

Sabita Mishra et al, International Journal of Advances in Agricultural Science and Technology,

Vol.8 Issue.7, July-2021, pg. 15-23

ISSN: 2348-1358

Impact Factor: 6.057

NAAS Rating: 3.77

\title{
Lockdown-2020 and Livelihood of Migrant Women Workers in Jharkhand
}

\author{
*Sabita Mishra; **Anil Kumar; ***Pragatika Mishra \\ *\&**Principal Scientists, ICAR-CIWA, Bhubaneswar, Odisha and ***SMS, GVT-KVK, Godda, Jharkhand \\ E-mail: sabitamshra@rediffmail.com \\ DOI: 10.47856/ijaast.2021.v08i7.002
}

\begin{abstract}
The entire globe faces a very precarious situation during pandemic Covid-19. During national lockdown in India, it was hazardous for the migrant labourers and more unsafe for women migrant workers. They came across many livelihood challenges like: employment, nutrition, government support, societal security, health facility, etc. which were repeatedly underlined in numerous mass media news. Therefore, to know the actual problems encountered by the women migrant returnees, this particular study was undertaken in Jharkhand state where most of women workers go on migration for earning. For the purpose, 41 women migrant returnees were randomly selected as respondentsfrom 18 villages covering five blocks of the state. By the use of a survey schedule, data was collected in the arena of socio-economic outline, place of migration, reason of migration, sector of engagement, income, difficulties confronted and support need from government for livelihood enhancement which are pronounced in this study.
\end{abstract}

Keywords: migrant women labourers, lockdown, livelihood

Introduction: Women face a number of challenges for their livelihood specially during natural disasters and disease pandemic. During covid-19 pandemic, women have encountered livelihood challenges in the field of wage earning, small business, family occupation, domestic exploitation, facilities from government, reduced employment opportunity, remuneration paid in time, etc. The nationwide lockdown in India affected livelihood of millions of women migrant workers across the country. They were hit hard while walking back home for hundreds of kilometres with no social safety and little access to family support. There were several reports of migrant woman who delivered baby while walking back home. The hardships faced by these women were highlighted in the media reports. Another report on migrant laborers in north India found that around $92 \%$ had lost their work, and $42 \%$ were negatively impacted with no food or supplies (Jan Sahas 2020). There were also reduced access to maternal, new-born and child health services, increased domestic violence, decline in employment, reduced social security, etc. COVID-19 has unevenly impacted women and girls in the domains of health, economy, social protection, and gender-based violence (UN 2020). The COVID-19 crisis is expected to have a long-term impact on informal sector workers (International Labor Organization 2020) as they are 


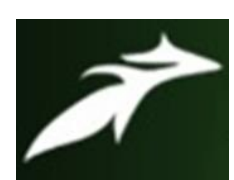

Sabita Mishra et al, International Journal of Advances in Agricultural Science and Technology,

Vol.8 Issue.7, July-2021, pg. 15-23

ISSN: 2348-1358

Impact Factor: 6.057

NAAS Rating: 3.77

the most vulnerable communities and are more exposed to the current global pandemic (Sengupta and Jha 2020). It was also reported that the care burden that COVID-19 would result in a long-term shock for poor people in the informal sector. Extreme poverty and food scarcity were flagged as issue for most informal sector workers (Khan and Mansoor 2020). A recent study analyzing the situation of women in Malaysia, Sri Lanka, Australia, and Vietnam, indicated that the COVID-19 outbreak had disproportionately impacted women, and they have an increased reproductive burden (McLaren et al. 2020). Keeping the above facts in view, an investigation was made in Jharkhand state of India to understand the actual livelihood problems faced by the women migrant workers during corona pandemic.

\section{About Jharkhand:}

Jharkhand being the 15th largest state by area, and 14th largest by population. It has an area of $79,710 \mathrm{~km}^{2}$ with 24 districts, 260 blocks, and 32,620 villages. The gross domestic product of Jharkhand is estimated at ₹3.83 lakh crore in 2020-21. The per capita GDP of Jharkhand in 2018-19 was 82,430. (Jharkhand Budget Analysis 2020-21). Agriculture is an important sector in the economy of Jharkhand besides the cottage industry and IT industry. Figures from the Ministry of Rural Development show that only 25.63 lakh out of Jharkhand's 53.36 lakh job cards are active - less than half. In all, Jharkhand has 91.75 lakh registered workers, of which 33.26 lakh are active (2020). Farmers in the state produce several crops, vegetables, milk and egg. Jharkhand is the pioneer state in implementing "Single Window System for farmers" with support of weather forecast, crop insurance, availability of seeds, market linkage etc. (Agriculture Scenario in Jharkhand, 2018).

According to the 2011 Indian Census, Jharkhand has a population of 32.96 million with 16.93 million males and 16.03 million females. About $39.1 \%$ of its population is below the poverty line. The state has a large number of work force in the unorganized sector. Approximately one lakh workers are employed in its construction projects out of which around 60,000 workers are local whereas the rest are hired migrant labourers. More than 7.0 lakh people of Jharkhand work in states like Gujarat, Maharashtra, Delhi, West Bengal, Odisha, Chhattisgarh, Tamil Nadu and Nagaland. Based on the report, out of total migrated labourers, nearly 5.0 lakh had returned by Shramik Special trains, buses and flights after national lockdown. Recent research showed that the pandemic had exacerbated the existing disparities, further deteriorating the conditions of poor and migrant workers (Che, Du, and Chan 2020; Baas 2020). The lives and livelihood of poor communities in south-Asian countries had also been disproportionately impacted by COVID-19 (Hamiduzzaman and Islam 2020) and similar observations were also seen for migrant workers in India (Bhagat et al. 2020). Migrant workers who remained in their urban enclaves also encountered similar experiences (The Hindu 2020; Bailwal and Taniya 2020).

\section{Migration Report of Jharkhand:}

The migrant workers are indispensable but mostly invisible key actors in cities' development. Rural migrants are socially portable, culturally stretchy and economically ambitious people. They are most susceptible to monetary exploitation. The contribution of migrants is estimated to be more than $10 \%$ to the country's GDP. India has a vast workforce with more than 450 million people in the informal sector (Sharma 2020). According to one estimate, about $90 \%$ of women work in informal sectors, of which $20 \%$ work in urban areas (Geetika, Singh and Gupta 2011). More recent numbers revealed that there 


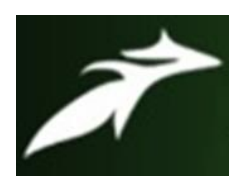

Sabita Mishra et al, International Journal of Advances in Agricultural Science and Technology,

Vol.8 Issue.7, July-2021, pg. 15-23

ISSN: 2348-1358

Impact Factor: 6.057

NAAS Rating: 3.77

are about 326 million internal migrants in India (NSSO, 2007-08) i.e. nearly $30 \%$ of the total population. Almost $70 \%$ of all the migrants are women.

\section{Materials and Methods:}

The study was conducted during September, 2020 in Jharkhand state of India covering 18 villages (Khatnai, Mohbanna, Maheshpur, Bariatha, Kasturia, Logay, Charka, Maheshlitti, Sondiha, Kurmichak, Shahri, Belbathan, Sondiha, Tulsikitta, Nonmati, Basbhitta, Chilra, Ghatbaghabandh) in five blocks like Godda, Basantrai, Pathargama, Poraiyahat and Mahagama. Jharkhand was purposefully identified as a large number of women workers migrate outside the state for their livelihood. A total of 41 women migrant returnees were randomly selected as respondents for data collection. A structured questionnaire on various aspects of the indicators of livelihood were taken for the study.

\section{Result and Discussion:}

Socio-Economic Profiles: Socio-economic profile of the respondents were studied with respect to age, education, marital status, size of land holding and major livelihood sources. The responses on the above aspects are classified in the following table.

Table 1. Socio-Economic profile of the respondents $(n=41)$

\begin{tabular}{|c|c|c|c|c|c|}
\hline \multirow[t]{2}{*}{1} & Age category & $21-30 \mathrm{yr}$ & $31-40 \mathrm{yr}$ & $41-50 \mathrm{yr}$ & Total \\
\hline & $\%$ respondent & 12.19 & 48.79 & 39.02 & 100 \\
\hline \multirow[t]{2}{*}{2} & Education level & Upto $7^{\text {th }}$ & Upto $10^{\text {th }}$ & Above $10^{\text {th }}$ & \\
\hline & $\%$ respondent & 39.02 & 46.34 & 14.64 & 100 \\
\hline \multirow[t]{2}{*}{3} & Marital status & Married & Unmarried & - & \\
\hline & $\%$ respondent & 87.81 & 12.19 & - & 100 \\
\hline \multirow[t]{2}{*}{4} & Size of landholding & Landless & Less than 1 acre & More than 1 acre & \\
\hline & $\%$ respondent & 9.75 & 90.25 & 0 & 100 \\
\hline \multirow[t]{2}{*}{5} & Sources of income & Farming & Wage earning & Any other & \\
\hline & $\%$ respondent & 87.81 & 12.19 & 0 & 100 \\
\hline
\end{tabular}

The above table revealed that, majority of the women migrant workers (48.79\%) were in the age group of $31-40$ years followed by $41-50$ years $(39.02 \%)$ while only $12.19 \%$ were in the age of $21-30$ years. It indicates that the most dynamic age for workers is 31 to 40 years when they are able to work hard. There is need for the government to focus on this particular age group (31-49 years) for any developmental work. Similarly, majority of the respondents were educated up to $10^{\text {th }}$ level $(46.34 \%)$ and married $(87.81 \%)$. Over $90 \%$ of the migrant women workers had less than one acre of cultivated land and farming was major livelihood source for $87.81 \%$ of them. None of the workers possessed more than one acre of land. The married women preferred to go as migrant workers with their husbands while the unmarried girls stayed back at their native places. 


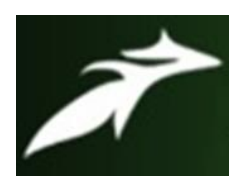

Sabita Mishra et al, International Journal of Advances in Agricultural Science and Technology,

Vol.8 Issue.7, July-2021, pg. 15-23

ISSN: 2348-1358

Impact Factor: 6.057

NAAS Rating: 3.77

Place of Migration: The respondents from Jharkhand choose Patna, Ranchi, Bhagalpur, Muradabad, Vardhaman, Begusarai and Rajkot in Bihar as the place of migration. Further, Odisha, Delhi, Maharastra, Dadar Nagar, Haweli, Hyderabad and West Bengal were the preferred places for women for migration other than their own state.

Reasons of Migration: The reasons for migration by the women respondents have been presented in Table 2.

Table 2. Reasons for migration by women $(n=41)$

\begin{tabular}{|c|l|c|}
\hline $\begin{array}{c}\text { Sl. } \\
\text { No. }\end{array}$ & \multicolumn{1}{|c|}{ Reasons of Migration } & \% respondent \\
\hline 1 & To earn money & 90.24 \\
\hline 2 & Not to stay with the in-laws & 0.00 \\
\hline 3 & For better education of the children & 0.00 \\
\hline 4 & To stay with husband & 9.76 \\
\hline 5 & Any other & 0.00 \\
\hline Total & $\mathbf{1 0 0 . 0 0}$ \\
\hline
\end{tabular}

The main reason of migration was the economic compulsion (90.24\%). To join their husbands working at far off places $9.76 \%$ women chose to migrate. For these migrant women workers, other reasons were not important. Therefore, if there would have been employment opportunities for these women they would not have migrated and hence livelihood opportunities should be created for them near their places of residences.

Period of Working: The duration of migration as revealed by these women respondents are given in Table 3.

Table 3. Duration of working as migrant worker (41)

\begin{tabular}{|c|l|c|}
\hline Sl. No. & \multicolumn{1}{|c|}{ Period of working } & \% respondent \\
\hline 1 & Less than 1 year & 0.00 \\
\hline 2 & $1-2$ years & 0.00 \\
\hline 3 & $2-3$ years & 4.88 \\
\hline 4 & $3-4$ years & 12.19 \\
\hline 5 & More than 4 years & 82.93 \\
\hline & Total & $\mathbf{1 0 0 . 0 0}$ \\
\hline
\end{tabular}

The period of working as migrant workers was more than four years for majority of the women (82.93\%). Only $12.19 \%$ and $4.88 \%$ of them worked for three to four years and two to three years, 


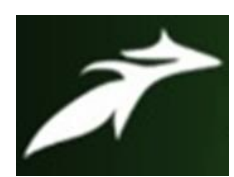

Sabita Mishra et al, International Journal of Advances in Agricultural Science and Technology,

Vol.8 Issue.7, July-2021, pg. 15-23

ISSN: 2348-1358

Impact Factor: 6.057

NAAS Rating: 3.77

respectively. All the respondents who were contacted worked for longer duration for over 3 years to continuously support their families.

Migration and Sector of Employment: The types of work taken up by the migrant women indicated that these women mostly took up the work of labour in brickkiln, cooking for others, construction workers etc. Over 90 percent of the migrant women took up work of one or the other kind and $7.3 \%$ of them migrated to join their husbands. Only $2.4 \%$ of these women migrated with their whole family.

Table 4. Migration and sector of employment $(n=41)$

\begin{tabular}{|c|l|c|}
\hline \multicolumn{2}{|l|}{ Pattern of migration } & $\%$ respondents \\
\hline i) & Self & 7.32 \\
\hline ii) & With husband & 90.25 \\
\hline iii) & With whole family & 2.43 \\
\hline \multicolumn{2}{|l|}{ Sector of employment during Migration } \\
\hline i) & No Work & 7.31 \\
\hline ii) & $\begin{array}{l}\text { Any other (brickkiln, cooking for } \\
\text { others, construction labour, factory, } \\
\text { sale counter of cloth shops etc.) }\end{array}$ & 92.69 \\
\hline
\end{tabular}

As depicted in the above table, most of the respondents had migrated with their husbands $(90.25 \%)$ while only $2.43 \%$ of them migrated with whole family. However, self-migration was observed in case of $7.32 \%$ of women who migrated neither with husbands nor with whole family. Furthermore, about $92.69 \%$ of women migrants were employed in the sectors like: Bhatti, construction, factory, selling clothes, in other homes as cook, etc. whereas, $7.31 \%$ of them had no work rather they had only accompanied their husbands at the time of migration.

Table 5. Earning of the migrant women $(n=41)$

\begin{tabular}{|c|l|c|}
\hline $\begin{array}{c}\text { Sl. } \\
\text { No. }\end{array}$ & Earning per Month & \% respondent \\
\hline 1 & No income & 7.31 \\
\hline 2 & Rs. 5000/- to Rs. 10000/- & 0.00 \\
\hline 3 & Rs. 10001/- to Rs. 15000/- & 92.69 \\
\hline 4 & Rs. 15001/- to Rs. 20000/- & 0.00 \\
\hline 5 & More than Rs. 20000/- & 0.00 \\
\hline & Total & $\mathbf{1 0 0 . 0 0}$ \\
\hline
\end{tabular}

The monthly earnings of the women workers were in the range of Rs 10000/- to 15000/- and it appears that they were all paid adequately earning Rs. 300 to $500 /$ - per day. 


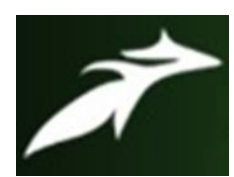

Sabita Mishra et al, International Journal of Advances in Agricultural Science and Technology,

Vol.8 Issue.7, July-2021, pg. 15-23

ISSN: 2348-1358

Impact Factor: 6.057

NAAS Rating: 3.77

\section{Problems Faced by Farm Women during Lockdown:}

The lockdown imposed to contain the spread of Covid-19 caused great hardship to the women workers because they were deprived of the regular they were earning. Since it was an extended lockdown, most of the employers did not pay them during this period. Similar observations were also reported by Mishra et al. (2021). According to Chakraborty (2020) women are potentially affected more because in many contexts they are considered to be less productive and subsequently have a lower position and rank in society. UN Women (2020) reported that women face loss of livelihood, suffer human rights violations besides other hardships when pandemic befall. The various social- psychological issues faced by women during the lockdown has been summarized in Table 6 .

Table 6 Problems faced by Farm Women during Lockdown

\begin{tabular}{|c|l|c|c|}
\hline S. no. & Problems faced during Lockdown & $\begin{array}{c}\% \\
\text { respondents }\end{array}$ & Rank \\
\hline 1 & Financial (job loss) & 100.00 & I \\
\hline 2 & Mental (fear, anxiety, stress, etc.) & 100.00 & I \\
\hline 3 & Nutritional (food, water, etc.) & 58.53 & II \\
\hline 4 & Social (violence, abuse, isolation, etc.) & 48.78 & III \\
\hline 5 & Medical (health care) & 4.87 & IV \\
\hline 6 & Shelter (rented house) & 0.00 & - \\
\hline 7 & Any other & 0.00 & - \\
\hline
\end{tabular}

Most of the respondents had lost their jobs and all of them faced severe financial constraints. According to Kamanga-Njikhoand Tajik (2020), Female-headed families are significantly affected by COVID-19 and are unable to meet household needs due to the lack of economic options. Simultaneously, cases of was mental stress, anxiety and fear were reported by all the women migrant workers. They had the fear of not being allowed to meet their family members upon return to home. Similar studies among the general population have been reported about significant psychological impacts of COVID-19 (Varshney et al. 2020). Additionally, $48.78 \%$ of respondents faced other social problems like violence, abuse and isolation while $58.53 \%$ had to pass the period without sufficient nutrition (food and water). The COVID19 crisis was likely to pose a challenge to food security and malnutrition (Khanna 2020). Dahir (2020) reported that the COVID-19 crisis is adding more complexity to hunger and estimated that 265 million people would face acute hunger by the end of 2020 . Further, only two of the respondents $(4.87 \%)$ faced the health issue and fortunately none of them had shelter (rented house) or any other problem. The situation is critical in countries like India during the pandemic, where access to healthcare for migrant workers is a challenge even in normal circumstances (Suresh, James, and Balraju 2020).

\section{Present Engagement after Return:}

When the women migrants lost their jobs at the place of work, they were bound to return to native places. Foley and Piper (2020) studied that the pandemic and subsequent measures to control its spread have posed profound social, economic, and structural challenges to migrant workers across 


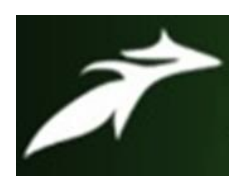

Sabita Mishra et al, International Journal of Advances in Agricultural Science and Technology,

Vol.8 Issue.7, July-2021, pg. 15-23

ISSN: 2348-1358

Impact Factor: 6.057

NAAS Rating: 3.77

many countries. The work taken up by these women upon return to their homes have been given in table 7.

Table 7. Present Engagement after return (41)

\begin{tabular}{|c|l|c|}
\hline SI. No. & Present Engagement after return & $\%$ \\
\hline 1 & Farming & 82.93 \\
\hline 2 & Wage earning & 14.64 \\
\hline 3 & Business & 2.43 \\
\hline 4 & Service & 0.00 \\
\hline 5 & Any other & 0.00 \\
\hline 6 & Total & 100.00 \\
\hline
\end{tabular}

Upon return to their homes, the migrant workers mostly took up farming $(82.9 \%)$ followed by wage earning $(14.6 \%)$ Only 2.43 of them took up petty business selling items from their homes. None of them found work in other sectors.

Support Need from Government: The support desired by these women have been summarized in table 8. Most of them looked to the government to help them tide over this unprecedented crisis.

Table 8. Support Need from Government (41)

\begin{tabular}{|c|l|c|c|}
\hline Sl. No. & Support Need from Government & $\mathbf{f}$ & $\%$ \\
\hline 1 & Free critical inputs & 41 & 100.00 \\
\hline 2 & Capacity building & 41 & 100.00 \\
\hline 3 & Bank credit & 41 & 100.00 \\
\hline 4 & Insurance & 0 & 0.00 \\
\hline 5 & Government Health Card & 0 & 0.00 \\
\hline 6 & BPL Card & 0 & 0.00 \\
\hline 7 & Free house & 0 & 0.00 \\
\hline 8 & Any other & 0 & 0.00 \\
\hline
\end{tabular}

The major three needs identified by all the respondents were access to bank credit, free critical inputs and capacity building. Therefore, governments should create credit facility along with free supply of critical inputs so that they are able to build their livelihood afresh. In addition, capacity building and training should also be given to these women migrants.

Conclusion: Adequate livelihood options with better wages should be created in village areas with viable schemes to provide avenues of employment in own locality. The slogan of 'Local is Vocal' should be given top priorityto reduce migration rate and simultaneously to bring back the migrants from cities to their own villages.The gender issues like discrimination, exploitation and trafficking should be prevented for migrant women workers. 


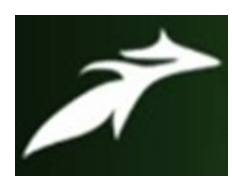

Sabita Mishra et al, International Journal of Advances in Agricultural Science and Technology,

Vol.8 Issue.7, July-2021, pg. 15-23

ISSN: 2348-1358

Impact Factor: 6.057

NAAS Rating: $\mathbf{3 . 7 7}$

\section{References:}

[1]. Agriculture Scenario in Jharkhand, Department of Agriculture, Animal Husbandry and Cooperative, Government of Jharkhand, 25 $5^{\text {th }}$ October, 2018.

[2]. Bailwal, Neha, and TaniyaSah (2020) "Travails and Travesties: The Plight of the Migrants Who Didn't Leave Delhi". The Wire. 26 June. Accessed 12 September 2020.

[3]. Bhagat, R.B., R. S. Reshmi, HariharSahoo, Archana K. Roy, and DiptiGovil (2020) The COVID-19, Migration, and Livelihood in India. Mumbai: International Institute of Population studies.

[4]. Chakraborty, Shiney (2020) "Increased Care Work, Reduced Wages: Informal Women Workers are Rarely Getting By". The Wire. 25 May. Accessed 12 September 2020.

[5]. Che, Lei, HaifengDu, and Kam Wing Chan (2020) "Unequal Pain: A Sketch of the Impact of the COVID19 Pandemic on Migrants' Employment in China." Eurasian Geography and Economics 1-16.

[6]. Dahir, AbdiLatif (2020) "Instead of Coronavirus, the Hunger Will Kill Us. A Global Food Crisis Looms". The New York Times. 22 April. Accessed 20 September 2020.

[7]. Foley, Laura, and Nicola Piper (2020) COVID-19 and Women Migrant Workers: Impacts and Implications. Geneva: International Organization for Migration.

[8]. Geetika, Tripti Singh, and AnvitaGupta (2011) "Women Working in Informal Sector in India: A Saga of Lopsided Utilization of Human Capital. "International Proceedings of Economics Development and Research 4: 534-538.

[9]. Hamiduzzaman, Mohammad, and M. Rezaul Islam (2020) "Save Life or Livelihood: Responses to COVID-19 among South-Asian Poor Communities." Local Development \& Society 1-13.

[10]. Hindu, The (2020) "96\% Migrant Workers Did Not Get Rations from the Government, 90\% Did Not Receive Wages during Lockdown: Survey". The Hindu. 20 April. Accessed 16 September 2020.

[11]. International Labour Organization (2020) ILO Monitor 2nd Edition: COVID-19 and the World of Work.

[12]. Jharkhand Budget Analysis 2020-21. PRS India. 23 March 2020.

[13]. Kamanga-Njikho, Veronica, and QandigulTajik (2020) "Female-headed Households Bear the Brunt of COVID-19 as Livelihood Gaps Increase". UNICEF.

[14]. Khan, Faraz, and KashifMansoor (2020) "COVID-19 Impact: Informal Economy Workers Excluded from Most Govt Measures, Be It Cash Transfers or Tax Benefits". First Spot. Accessed 11 September 2020.

[15]. Khanna, Anoop (2020) "Impact of Migration of Labour Force Due to Global COVID-19 Pandemic with Reference to India." Journal of Health Management 22 (2): 181-191.

[16]. McLaren, H J. Wong, K R. K N. Nguyen, Komalee Nadeeka Damayanthi. Mahamadachchi (2020) Covid-19 and Women's Triple Burden: Vignettes from Sri Lanka, Malaysia, Vietnam and Australia Social Sciences 9 (5): 87.

[17]. Mishra, Sabita and Kumar, Anil (2021) Farm women facing the challenges of Covid-19 in Odisha. International Journal of Agriculture Sciences, ISSN: 0975-3710 \& E-ISSN: 0975-9107, Volume 13, Issue 2, 2021, pp.-10647-10650.

[18]. NSSO (2007-08), Migration report of Jharkhand.

[19]. Pachauri, Swasti (2020) "COVID-19 Outbreak Brings Attention Back to Informal Sector."Down to Earth. 23 March. Accessed 11 September 2020.

[20]. Power, Kate (2020) "The COVID-19 Pandemic Has Increased the Care Burden of Women and Families." Sustainability: Science, Practice and Policy 16 (1): 67-73.

[21]. Sahas, Jan (2020) Voices of the Invisible Citizens: A Rapid Assessment on the Impact of COVID-19 Lockdown on Internal Migrant Workers. New Delhi: Jan Sahas.

[22]. Sengupta, Sohini, and Manish K.Jha (2020) "Social Policy, COVID-19 and Impoverished Migrants: Challenges and Prospects in Locked down India." The International Journal of Community and Social Development 2 (2): 152-172. 


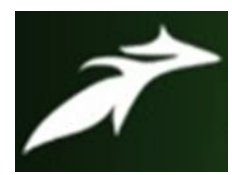

Sabita Mishra et al, International Journal of Advances in Agricultural Science and Technology,

Vol.8 Issue.7, July-2021, pg. 15-23

ISSN: 2348-1358

Impact Factor: 6.057

NAAS Rating: 3.77

[23]. Sharma, Yogima Seth (2020) "National Database of Workers in Informal Sector in the Works". The Economic Times. January 19. Accessed 15 September 2020.

[24]. Suresh, Rajani, Justine James, and RSjBalraju (2020) "Migrant Workers at Crossroads-The COVID-19 Pandemic and the Migrant Experience in India." Social Work in Public Health 35 (7): 633-643.

[25]. UN Women (2020) "Guidance Note: Addressing the Impacts of the COVID-19 Pandemic on Women Migrant Workers."

[26]. Varshney, Mohit, Jithin ThomasParel, NeerajRaizada, and Shiv KumarSarin (2020) "Initial Psychological Impact of COVID-19 and Its Correlates in Indian Community: An Online (FEEL-COVID) Survey." Plos One 15 (5): e0233874. 